\title{
The "London" Australian natural history drawings of Ferdinand Bauer (1760-1826) - revisited
}

\begin{abstract}
Mabberley, D. J.: The "London" Australian natural history drawings of Ferdinand Bauer (17601826) - revisited. — F1. Medit. 31 (Special Issue): 67-94. 2021. — ISSN: 1120-4052 printed, 2240-4538 online.

Since the catalogues of the zoological (1994) and botanical and landscape (1999) drawings of Ferdinand Bauer in the Natural History Museum, London were published, it has been possible to refine the attributions of the "finished" watercolours held there through examination of more of the original field drawings held at the Archiv, Naturhistorisches Museum Wien. As a result, locality and chronology information for many zoological and botanical drawings held in London are updated here. Such precision has bearing on phenology of the germane plant species in light of climate-change and distributions now reduced through European land-use practices. In an appendix there is discussion of the drawings attributed to Bauer and now held in the Linnean Society of London; some are possibly the work of Franz Bauer.
\end{abstract}

Key words: Ferdinand Bauer, London watercolours, Australian biota.

\section{Introduction}

The enormous scientific output of Sandro Pignatti (and Erika Pignatti-Wikus) extends from the Mediterranean to Australia and includes an important comparison of the ecosystems of the Mediterranean with those of Western Australia (Pignatti-Wikus \& al. 2002). In celebrating Sandro's ninetieth birthday, it seems appropriate, then, to discuss the work of another whose ambit similarly spanned the Mediterranean and Australia, namely the Austrian natural history painter, Ferdinand Bauer (1760-1826), coincidentally another of Erika's subjects of research (Pignatti-Wikus \& al. 2000a, 2000b; Mabberley \& al. 2007).

Ferdinand Bauer's work on Mediterranean plants and animals in the field and studio (1786-99) leading to the monumental Flora graeca (1806-40) of John Sibthorp and James Edward Smith is well documented (Lack with Mabberley 1999; Mabberley 2017: 22-57) and is a relatively straightforward topic of research, as most of the germane materials are held in one place, namely Oxford, England. By comparison, Bauer's Australian work is much less so, because his materials are in both London and Vienna, with the latter yet to be completely catalogued and digitised. 


\section{Ferdinand Bauer in Australia}

In 1800 Bauer was recruited by Sir Joseph Banks to be natural history painter on the Investigator voyage (1801-05) of Matthew Flinders to Australia (Britten 1909; Stearn 1960; Mander-Jones 1965; Bauer 1976; Mabberley 1985 passim; Norst 1989; Watts \& al. 1997; Mabberley \& Moore 1999; Mabberley 1999 passim; Pignatti-Wikus \& al. 2000a, 2000b; Mabberley 2002; Lack 2003, 2015 passim; Mabberley 2017: 76-173, 2019: 175-217, 232-43). As in the Mediterranean, Bauer used a colour-coding system ("painting by numbers") to capture the natural appearance of both plants and animals of Madeira, South Africa, Australia and Indonesia (Timor). Each tone was assigned a number used in pencil sketches made in the field, allowing the true coloration to be recovered in Europe later. This system had been used by Bauer and his brothers in childhood when they were required to copy coloured illustrations of expensive plate-books in the library of a local monastery in what is now Valtice (Czechia). It would appear that such coding used on pencil sketches of images copied from the books allowed the boys to complete their watercolours elsewhere, thereby avoiding possible paintdamage to the originals (Mabberley 2017: 6). According to Riedl-Dorn \& Riedl (2019), such numbering was used at this time by children colouring maps, so it was likely not a novelty in Valtice, but, with the exception (Mabberley \& San Pío Aladrén 2012) of the Bohemian Thaddaeus Haenke (1761-1816) in South America (1789-1816), Ferdinand Bauer was the only significant artist so far known ever to use it such a system in the field. Among those colourcharts in use in Central Europe by the end of the eighteenth century, Franz Estner's Versuch einer Mineralogie (1794; Fig. 1) was certainly employed in some circumstances by Bauer, notably in drawing a sea-slug (Bauer MS: "see of Estners Mineral Tables for all of this", "Norfolk Island Dec 21 1804") but also noted on drawings of some subjects from northern Australia before that - and his copy of the book was still amongst his chattels when he died (Mabberley 2017: 10-11, 153, 219). Although a "Bauer'sche Farbtabelle" was reportedly used in 1860 to "interpret" a pencil sketch made by Bauer of the now extinct Norfolk kaka (Nestor productus (Gould)), a bird drawn on Norfolk Island in January 1805 (Mabberley 2017: 160-61, Riedl-Dorn \& Riedl 2019), it has yet to be demonstrated that Bauer's system of 1000 colourshades (200 of green alone) used in Australia was generally based on Estner's scheme, or another (lost) system Bauer may have elaborated - or, in view of the speed with which he worked, was in practice, partly or even wholly, just in his head in any case - rather in the way composers use musical notation (Mabberley \& San Pío Aladrén 2012). That any chart available after Bauer's death must have been difficult to use is shown by the singularly unfaithful results in a half-finished watercolour of the Western Australian Stylidium nymphaeum Wege (Mabberley 2017: 66-89), elaborated in Vienna, possibly by the Zehner brothers, who may have also prepared the rather gaudy watercolours of at least some of Bauer's Australian fungi there, so different from the germane finished watercolours of Bauer in London, yet both elaborated from Bauer's field drawings. Certainly, no such Bauer chart survives at W today. Nonetheless, using the colours of living plants in Western Australia, it has been possible to crack Bauer's Australian code by assigning colours to the numbers on Bauer's pencil drawings made there in 1801-2 and now preserved in the Naturhistorisches Museum Wien (Pignatti-Wikus \& al. 2000a, 2000b). Moreover, using "reverse engineering" it has been possible for a modern Australian botanical artist, Marion Westmacott, to use the reconstructed code to produce a watercolour from Bauer's numbered pencil drawings (Fig. 2) of a now-extinct tree, Solanum bauerianum Endl. 


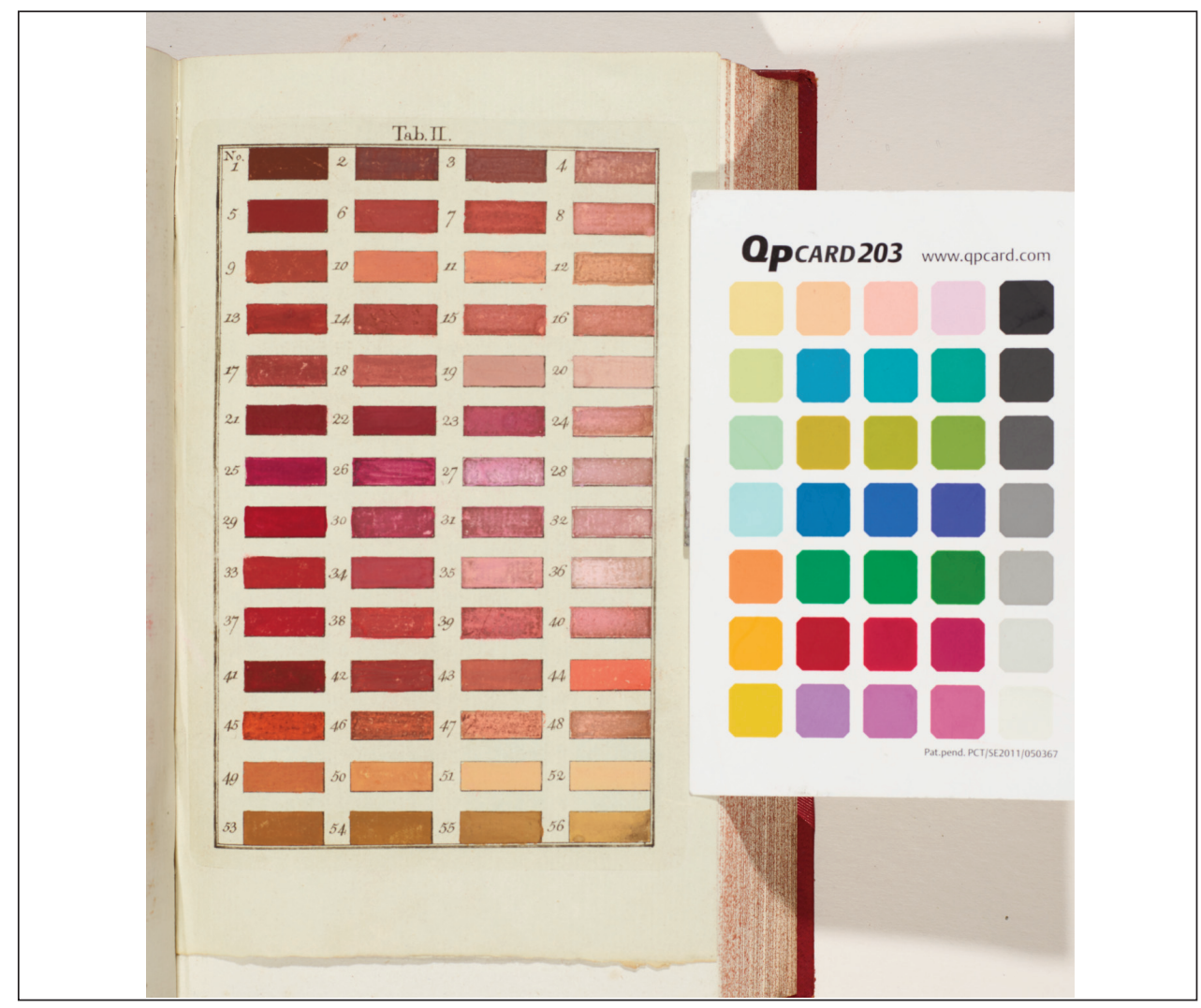

Fig. 1. Franz Estner's Versuch einer Mineralogie (1794) (Natural History Museum, London).

(Solanaceae; Mabberley \& al. 2007; Mabberley 2017: 156-159), so that modern biologists now know what looked like (Fig. 3).

Although Bauer was technically "line-managed" by Flinders's naturalist, the Scottish botanist, Robert Brown (1773-1858), in Investigator's circumnavigation of Australia (180103), he often worked independently and made his own herbarium, most of which survives in Vienna (W), with some Norfolk Is. duplicates owned by Brown now at Kew (K; not with Brown's own herbarium now at the Natural History Museum in London (BM), which includes a small number of Bauer's Australian duplicates; Mabberley 1985 passim; Mabberley \& Moore 2021). In general, the $\mathrm{W}$ specimens are the bases for Bauer's surviving field-drawings in W, though it is clear that he sometimes used Brown's or even other collectors' material, as this is sometimes noted in his often idiosyncratic English on the Vienna drawings (e.g. unidentified pencil sketches with numbers (HPV ${ }^{1}$ 384) "Sydney Sept 101803 by [Alexander] Gordon [see Mabberley 2019: 186]" "No 1341" and (HPV 391) "No 1318" "Duck Bruch [Duck River Bridge] Parramatta [New South Wales] Mr Brown Ap[ril] 12 1805"). Besides localities, Bauer seems to have started adding dates from "North Coast" in December 1802, after Gulf of Carpentaria "Island h [North Island or Barranyi, Northern Territory]" to his sketches, but there 


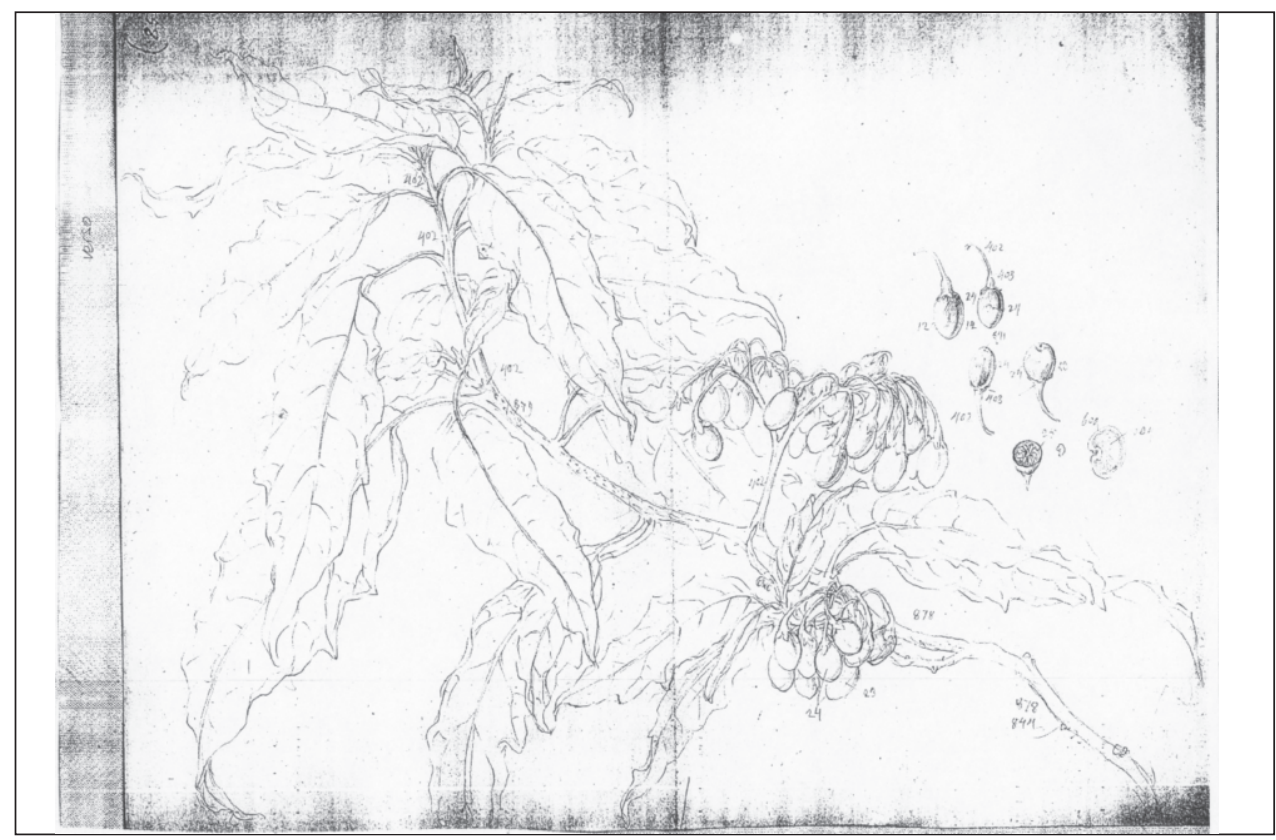

Fig. 2. Solanum bauerianum Endl. (Solanaceae). Field drawing of fruiting branches by Ferdinand Bauer, Norfolk Island, 1804-05 (Archiv, Naturhistorisches Museum Wien).

is no record of why he did this, but, in using his records, it is possible, by using referring to Brown's diary (Vallance \& al. 2001), to know precisely where Bauer's drawings were made.

\section{Ferdinand Bauer in London}

Besides amassing his own herbarium, Bauer also collected seeds, some of which subsequently germinated at Kew Gardens, where, after the voyage, he also made colour-coded pencil drawings of plants grown from seeds collected by Brown's whole team. Such include as yet unidentified legumes (HPV 1721) "Van Dimons I [sic = Tasmania, which Bauer never visited, so raised from seeds collected by Brown himself] Kew April 14 1809" [part enlarged "magnifit", i.e. "magnified"] and (HPV 1766), "Van Diemans Islan [sic = Tasmania] Mr Brown Kew May $3^{\text {th }}$ 1808", while that of what is likely a Pelargonium (HPV 1557) has "May 31808 Kew Port Jackson No X [Port Lincoln, South Australia] South Coast", which were raised from seeds collected by Peter Good (d. 1803) the gardener on Investigator. Sometimes Bauer made such "Kew" drawings on the verso of his field ones, e.g. unidentified HPV 942, though very often in the field, especially on Norfolk Is. (as with Solanum bauerianum) he drew the fruits (Fig. 2) on that side, the flowers being on the recto. Bauer also made drawings with colour-code numbers elsewhere as in the great London nursery of Conrad Loddiges (Mabberley 2019: 249, 292, 298), e.g. an unidentified legume (HPV 1767), "Loddige [sic] June $5^{\text {th }} 1807$ ". 


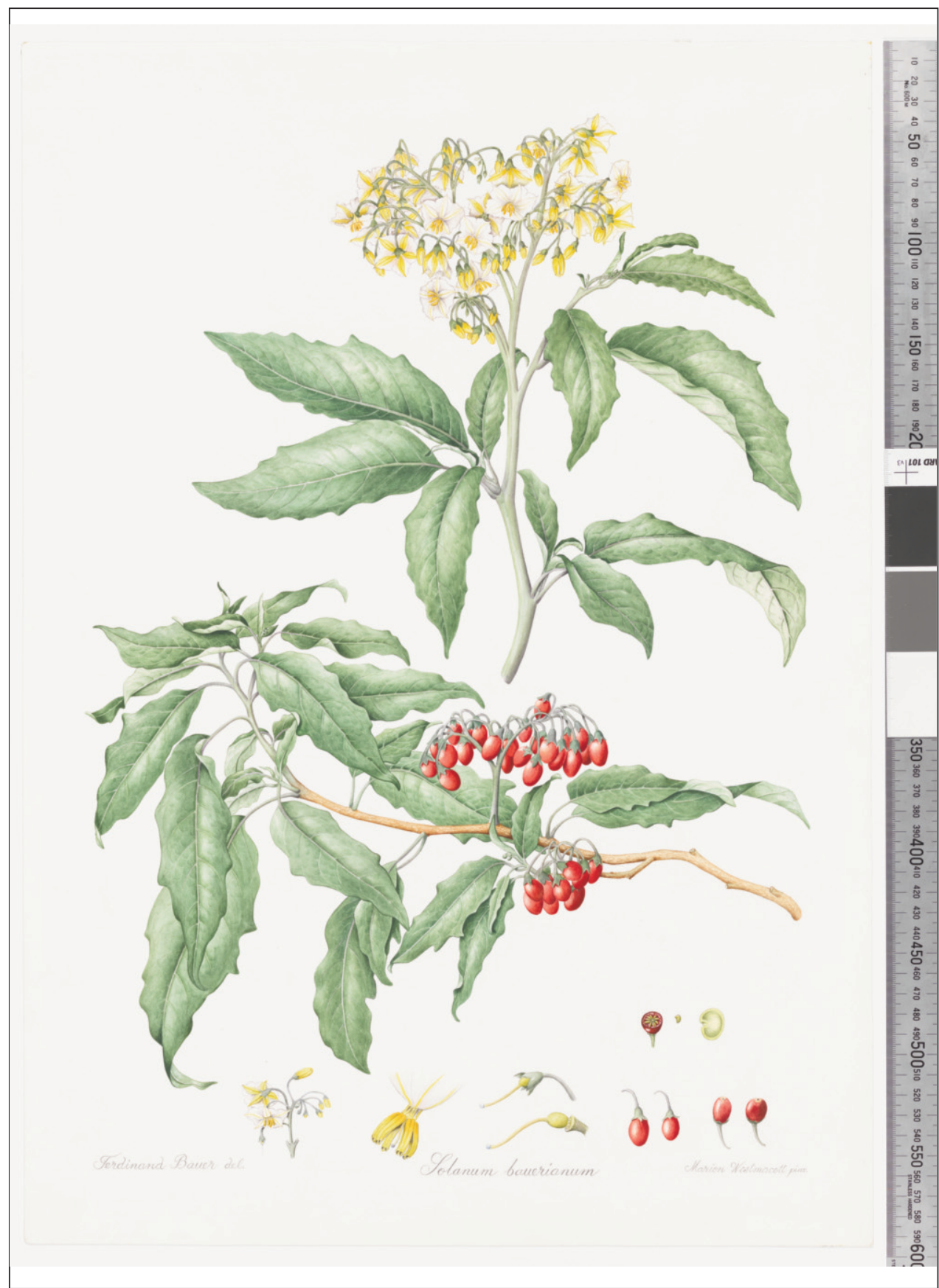

Fig. 3. Solanum bauerianum Endl. (Solanaceae). Watercolour by Marion Westmacott (Katoomba, New South Wales), "reverse-engineered" from Bauer's field-drawings interpreted according to the code cracked by Pignatti-Wikus \& al. (2001a, b). Courtesy the artist. 
Bauer's drawings were intended to be the basis for illustrations for a grand Flora of Australia in the style of Flora Graeca, to be written by Brown. After Brown's and Bauer's return to England in 1805, the British Admiralty paid their salaries, in Bauer's case until the end of 1811. Bauer worked up watercolours (some of the so-called "duplicates" possibly in Sydney before leaving Australia), using his colour-coded sketches.

Some, at least, were elaborated with details from his own herbarium specimens (Mabberley 2017: 108-111). During that time, Brown, in the mode of J. E. Smith's Prodromus (1806-07) for Flora Graeca, produced the first (and only) part of his Prodromus florae novae hollandiae (1810), but the ending of state support meant that the main Flora project was aborted and none of the 235 watercolours Bauer made for it was to be published until the 1960s. Nonetheless, Brown used them in his work, notable being that of Prasophyllum baueri (R. Br.) Poir. (Orchidaceae), nowadays an endangered species (Grimm \& al. 2020), Bauer's finished watercolour being the sole basis for Brown's description and therefore the holotype of Brown's then monospecific genus Genoplesium. The field-drawing in Vienna (Fig. 4) reveals that the material drawn was from Farm Cove, now the site of the Royal Botanic Garden Sydney.

Later, several of Bauer's completed drawings of Australian fish were again the sole basis for the descriptions, by John Richardson (see Appendix 3), and these holotype drawings are also preserved in London (Mabberley 2017: 96-97). Even in the mid-twentieth century, one of Bauer's Australian plant pencil sketches in Vienna became a holotype, namely that of Clerodendrum heterophyllum var. baueri Moldenke (i.e. ?Volkameria inermis L., Labiatae/Lamiaceae) in Phytologia 4: 127 (1952), which was based on HPV ${ }^{\mathrm{i}}$ 968a, drawn at Keppel Bay, Queensland in August 1802.

With the abandonment of the grand Flora project, Bauer, with Brown's help, himself began to publish fascicles of new versions of his drawings of Australian plants, his Illustrationes florae Novae Hollandiae (1813-16). He also made illustrations for Matthew Flinders's Voyage to Terra Australis of 1814, while, after Bauer's death, his field drawings were used by yet others, especially Stephan Endlicher (Mabberley \& Moore 1999: 206221). In 1814 Bauer returned to Vienna and issued the third and final fascicle (each fascicle comprising five plates) of his Illustrationes; Brown was effectively his agent for sales in Britain (Mabberley 2017: 194-196, 2019: 236-237; Watt 2004). Again, sometimes the localities can be ascertained from the annotated colour-coded field drawings in Vienna. Examples include: Pterostylis grandiflora (Orchidaceae; HPV 389) "Wallamula [Woolloomooloo] Sydney Jan 17 1804" "No 1317", likely the basis for his t. 2; Levenhookia pusilla (Stylidiaceae; HPV 813) [King George Sound; drawn from a Brown specimen (Mabberley \& Moore 1999: 84)], the basis for his t. 15 (bottom); Stylidium calcaratum (Stylidiaceae; HPV 824) "King George III S" the basis for his t. 15 (top left; Mabberley, 2017: 198).

Bauer also made for himself watercolours (on paper with watermarks from 1811) based on his drawings of animals he had sketched in the Pacific (Mabberley 2019: 232). These drawings he bequeathed to his brother Franz, in London, and are now in the Natural History Museum there. After Ferdinand's death, when his field-drawings of plants and animals were bought by the Emperor, some of those from both the Australian mainland and also Norfolk Is. and Timor were traced and lithographs made in Vienna, some (a few unpublished ones surviving) apparently for an aborted Flora of Norfolk Island of which 


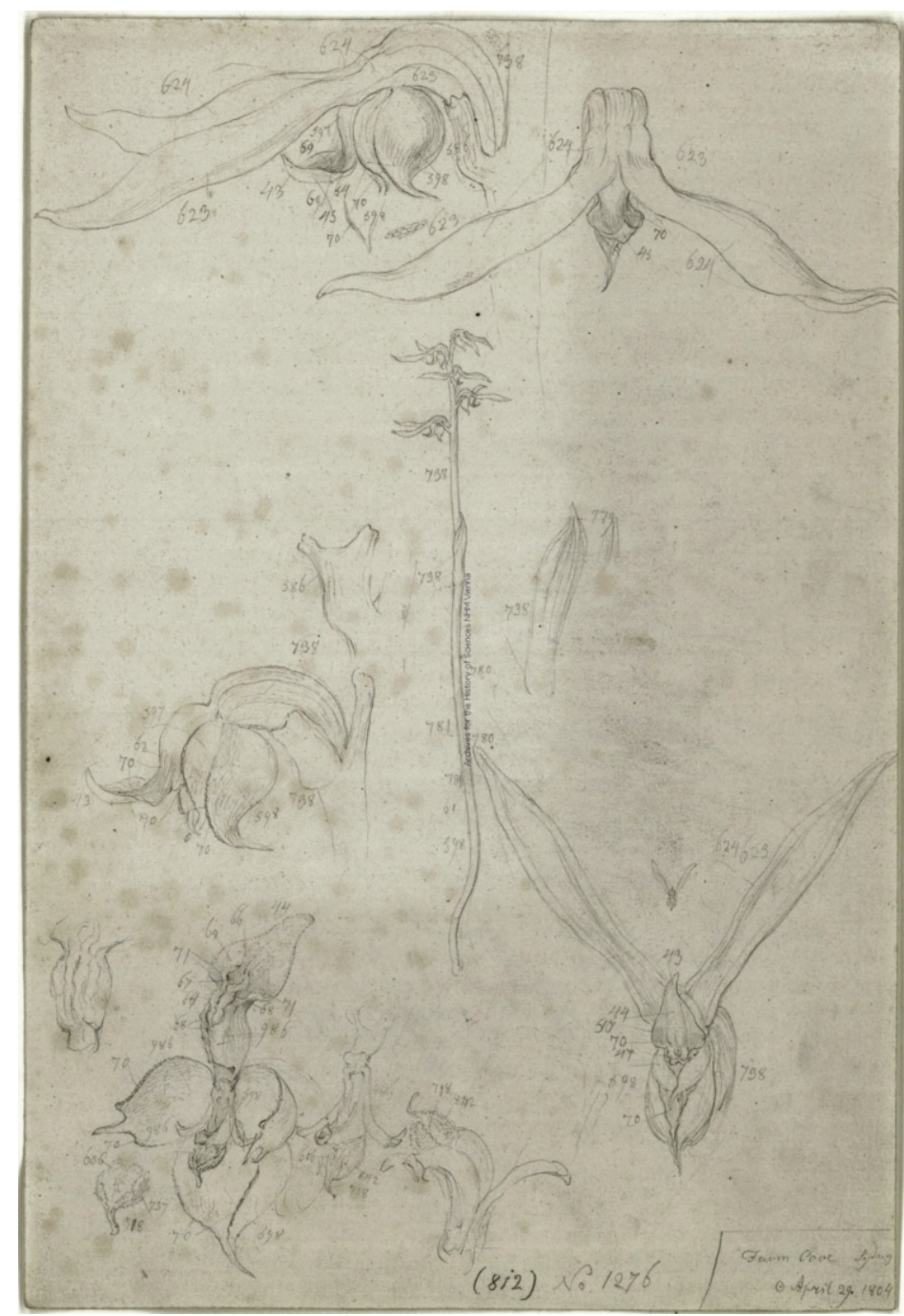

Fig. 4. Prasophyllum baueri (R. Br.) Poir. (Orchidaceae). Field drawing by Ferdinand Bauer, Farm Cove, Sydney, 29 April 1804. Previously unpublished, it is the basis for the London watercolour which is the holotype of Genoplesium baueri R. Br. (Archiv, Naturhistorisches Museum Wien).

Endlicher published a Prodromus (1833; Mabberley 2017: 210-12), others being used in his Iconographia and Atakta (Mabberley \& Moore 1999). Such field drawings revealing precise type localities include Morgania pubescens R. Br. (Endl., Iconographia t. 103 (1840); without HPV no.; i.e. Stemodia pubescens (R. Br.) W. R. Barker, Scrophulariaceae) - partly inked pencil tracing without numbers "Broad Sound 16. 1647.)" "Morgania"; Mazus pumilio R. Br. (Mazaceae; Endl., Iconographia t. 102 (1840); without HPV no.) - partly inked pencil tracing without numbers "1644"; [Dentella repens J.R. 
Forst., Rubiaceae] (Endl., Atakta: t. 13 (1834); HPV 867) - pencil drawing with numbers "No 457" "Gulf of Carpentaria Isl h" [North Island] (Mabberley \& Moore 1999: 210). In such cases, where new species were being described, Bauer's field drawings, sometimes backed by surviving herbarium specimens can be part of the original material in the context of typification matters.

\section{The Natural History Museum London drawings}

Although Bauer's 203 bound Admiralty drawings (three volumes) were used as “conversation pieces" (at least one drawing had by then already been lost), they eventually came to the British Museum in 1843 and into the care of Brown (Mabberley \& Moore 1999: 87-88), who had also personally acquired the finished botanical and zoological watercolours from Bauer's brother Franz's sale in 1841. After Brown's death in 1858, these 49 (of which 16 were "duplicates" of the Admiralty set) also came to the collections of what is now the Natural History Museum, London and all the "finished" drawings were thus forever divorced from the original field-drawings of Australian animals and plants in Vienna. As it is usually only the field drawings that indicate the provenance of the finished watercolours in London, the value of the latter is diminished. This is particularly pertinent where, as in the case of a number of fish and at least one orchid (see above), descriptions of new species were based solely on the unpublished watercolours.

The aim of this study is to begin to reconcile these resources.

\section{Published catalogues of the "London" drawings}

Wheeler \& Moore (1994) presented a catalogue of the 52 zoological drawings held at the Natural History Museum in London; Mabberley \& Moore (1999) presented one of botanical (236 with a and b series for some orchids etc., though $219 \& 220$ are not by Bauer) and landscape (4 of Norfolk Is.) ones held there. The localisations in both papers were, in the main, based on MSS and specimens in the Natural History Museum London, though Mabberley \& Moore (1999) cited a number of original field drawings, by then seen in Vienna or whilst they were on loan in Australia. As Mabberley \& Moore (1999: 83-84) pointed out, these are the critical sources of dates and localities for the subjects depicted in the finished drawings. In connexion with a number of other projects (e.g. Mabberley $2017,2019)$ the author has had the opportunity to examine all the Ferdinand Bauer materials held in the Naturhistorisches Museum Wien, where most are housed in the Archiv.

\section{The fate of the field drawings}

It would appear that almost all of the zoological field drawings survive in the Archiv, including the originals from which the "finished" drawings now in London were prepared, but most are unnamed. For the botanical drawings the situation is much more unsatisfactory, which is why no accurate number of Bauer's output can be arrived at (see Appendix 1). In 1889, many of the botanical field drawings were attached to Bauer specimens in the 
herbarium, because otherwise they, as artworks, were to be removed from the Botany Department to the Kunsthistorisches Museum in Vienna. Along with the original field drawings (all given HPV numbers in series according to the country where made) there were the tracings made for the production of a number of published and unpublished plates (see above) made from them (given "a", "b" etc. suffixes to the HPV numbers). Where more than one taxon was on a drawing, this was of course problematical in terms of its placing in the herbarium.

In 1945, some days after the armistice in World War II, a fire broke out in one of the rooms in an otherwise empty country house in Lower Austria, where part of the Vienna herbarium had been evacuated. No-one has recorded who was responsible, though there have been rumours of people burning the collections to keep warm (but it was summer) or for cooking, or even of vandalism by drunken Russian soldiery occupying that area. Certainly not only that room was burnt out, but the hall of the Schloss was also damaged. Riedl (1981) listed the "destroyed families" in that disaster and these include most of the Monocotyledones (though the orchids were kept separate, so did not suffer), the gymnosperms and many "Dicot" families such as important Australian ones like Proteaceae. On the face of it, then, all the drawings in the "destroyed families" were lost, but this is not so.

Examination of surviving drawings in the Archiv shows that some from the "destroyed" families survive, so were either apparently never added to specimens, or, as some herbarium material from these families has also survived, the drawings filed with them were not burnt (see Appendix 2 for germane examples related to the London drawings). Others include some Piperaceae, Casuarinaceae (Mabberley 2017: 134-35), Hydrocharitaceae (Mabberley 2017: 143) and even Proteaceae, as with [Persoonia pinifolia] (HPV 507: "Sydney Jan 1 1804" "No 166"; [verso, fr.] "Sydney Sep 1803". This may not be unconnected with the fact that in the Archiv today, some drawings are filed in very old paper folders, apparently their contents having been arranged by family, suggesting that some drawings at least were long ago retrieved from (or never added to) the herbarium. Again, those field drawings of such plants depicted on the same sheets as species not in "destroyed" families sometimes also survive (if they were filed under the latter). Others may have been on loan to workers outside Vienna during the war.

In the late twentieth century, an effort was made to extract the Bauer drawings and associated artwork from the herbarium collection for proper conservation in the Archiv, sadly without either recording where in the herbarium they had come from or leaving photographs of them in place in the collection. Most (but not all - see below) of the drawings etc. bear "HPV" numbers which would have been traceable through the acquisitions register, which would also have revealed how many drawings there were, as, where more than one taxon appeared on a sheet, each was given a number so that the HPV ticket bears e.g. "747-49". Very regrettably this invaluable document is lost.

In view of that, one has to turn to the problematic Brown list of Bauer's drawings (B. 97) in the Natural History Museum, London (Appendix 1), when it becomes clear that a number of drawings of taxa, at least from non-"destroyed" families (though possibly some of those too - see above), must still be in the collection. However, yet again, this is not straightforward, because the numbers Brown used for e.g. Compositae/Asteraceae, Labiatae/Lamiaceae [incl. "Verbenaceae" sensu auctt.], Myoporaceae [= Scrophulariaceae], Campanulaceae [incl. Lobeliaceae], Stylidiaceae, Violaceae, most Malvaceae and Dilleniaceae are on none of the surviving drawings of plants in those families found in the Archiv, so that it will be very diffi- 
cult, using surviving resources, to track down such drawings unless every herbarium folder of those families containing material from the germane countries is examined.

On the other hand, scrutiny of Brown MSS (B.65 of Moore 2021) has thrown light on the precise localities of some of Bauer's drawings where the originals were lost in the fire (Mabberley \& Moore 1999 passim), but, for some others, it will never be possible to improve on the tentative attributions already published, unless citations of these are published in literature or manuscripts yet to be identified.

\section{Conclusion}

The new findings are set out in Appendix 2 and 3. Bearing in mind that many of the botanical field drawings were of plants in the "destroyed families" (but see caveats above), a very high proportion of the drawings which were the bases for Bauer's published drawings, besides the Admiralty watercolours unpublished in his lifetime, have now been found.

What is needed next is a joint Austrian/Australian project to digitize all the Bauer fielddrawings in W and identify them: they represent important cultural heritage of both Austria and Australia. Only with the successful execution of such an international co-operative effort, of the kind championed by Sandro and Erika Pignatti, can the full scientific importance of the Vienna drawings be appreciated.

\section{Acknowledgements}

The author is grateful to Christa Riedl Dorn and Mario Riedl for facilitating access to Bauer drawings in the Archiv of the Naturhistorisches Museum Wien in 2014; this visit was enabled through the State Library of New South Wales in connection with the book (Mabberley 2017) and website (https://paintingbynumbers.dxlab.sl.nsw.gov.au/), Painting by Numbers, two endeavours supported by the Belalberi Foundation and thus the good offices of Peter Crossing AM (Sydney). Other colleagues at W, namely Heimo Rainer and Tanja Schuster, have provided more recent insights on drawings as yet unincorporated in the Archiv. Bob Chinnock (AD) kindly identified the Eremophila drawing discussed in Appendix 4 while Walter Lack (B) has been helpful in sharing his knowledge on the work of the Bauer family.

\section{References}

Bauer, F. L. 1976: The Australian flower paintings of Ferdinand Bauer. - in: Stearn,W. T. \& Blunt, W. (eds). - London.

Britten, J. 1909: Ferdinand Bauer's drawings of Australian plants. - J. Bot., London 47: 140-147.

Clarkson, J. R. \& Mabberley, D. J. 2005: Under the watchful eye of centinels: Robert Brown at the Pennefather River. - Roy. Geogr. Soc. Qld, Geogr. Monog. 10: 109-131.

Grimm, W. A., Weston, P. H., Manea, A. \& Leishman, M. R.: 2020: Life-cycle and natural history of the endangered terrestrial orchid Genoplesium baueri in eastern New South Wales. Cunninghamia 20: 265-271.

Lack, H. W. 1998: Recording form in early nineteenth[-]century botanical drawing. Ferdinand Bauer's “cameras". - Curtis's Bot. Mag. 15: 254-274. 
- 2003: Ferdinand, Joseph und Franz Bauer: Testamente, Verlassenschaften und deren Schicksale. - Ann. Naturhist. Mus. Wien 104B: 479-551.

- 2015: The Bauers: masters of botanical illustration. - London.

— with Mabberley, D. J. 1999: The Flora Graeca story: Sibthorp, Bauer and Hawkins in the Levant. - Oxford.

Mabberley, D. J. 1985: Jupiter botanicus. Robert Brown of the British Museum. - London.

- 1999: Ferdinand Bauer: the nature of discovery. - London.

- 2002: Ferdinand Bauer. - Pp. 50-68 in Thomas, S. (ed.) The Encounter, 1802: art of the Flinders and Baudin voyages. - Adelaide.

- 2017: Painting by numbers: the life and work of Ferdinand Bauer. - Sydney.

- 2018: An inconvenient truth? Notes on Australian plants in Persoon's Synopsis Plantarum (18067). - Austral. Syst. Bot. Newsl. 174: 7-10.

- 2019: Botanical Revelation: European encounters with Australian plants before Darwin. The Peter Crossing Collection. - Sydney.

— \& Moore, D. T. 1999: Catalogue of the holdings in The Natural History Museum (London) of the Australian botanical drawings of Ferdinand Bauer (1760-1826) and cognate materials relating to the Investigator voyage of 1801-1805. - Bull. Natur. Hist Mus., Bot. Ser. 29: 81-226.

— \& - 2021 (in proof): The Robert Brown Handbook: a guide to the life and work of Robert Brown (1773-1858), Scottish botanist [Regnum Vegetabile 160]. - Glashuitten.

— \& San Pío Aladrén, M. P. 2012: La carta de colores de Haenke de la Expedición Malaspina: un enigma - Haenke's Malaspina colour-chart: an enigma. - Madrid.

—, Pignatti-Wikus, E. \& Riedl-Dorn, C.: 2007: An extinct tree "revived". - Curtis's Bot. Mag. 24: 190-196.

Mander-Jones, P. 1965: The artists who sailed with Bauer and Flinders. - Proc. Roy. Soc. Australasia, South Aus. Br. 66: 17-31.

$†$ Moore., D. T. 2021 (in proof). Robert Brown's botanical manuscripts at the Natural History Museum London. - In: Mabberley, D. J. \& †Moore, D. T.: The Robert Brown Handbook: a guide to the life and work of Robert Brown (1773-1858), Scottish botanist [Regnum Vegetabile 160]. - Glashuitten.

Norst, M. J. 1989: Ferdinand Bauer; the Australian natural history paintings. - London.

Pignatti, E., Pignatti, S. \&. Ladd, P. G. 2002: Comparison of ecosystems in the Mediterranean Basin and Western Australia. - Pl. Ecol. 163: 177-186.

Pignatti-Wikus, E., Riedl-Dorn, C. \& Mabberley, D. J. 2000a: Ferdinand Bauer's field drawings of endemic Western Australian plants made at King George Sound and Lucky Bay, December 1801 - January 1802. I. - Rend. Fis. Acc. Lincei ser. 9, 11: 69 -108.

-,$\&-2000 \mathrm{~b}$ : Ferdinand Bauer's field drawings of endemic Western Australian plants made at King George Sound and Lucky Bay, December 1801 - January 1802. II. - Rend. Fis. Acc. Lincei ser. 9, 11: 201-244.

Riedl, H. 1981: Families destroyed in World War II at the Vienna Herbarium (W). - Taxon 30: 727-728.

Riedl-Dorn, C. \& Riedl, M. 2019: Ferdinand Bauer or Johann and Joseph Knapp? A rectification. Gard. Bull., Singapore 71 suppl. 2: 123-142.

Stearn, W. T. 1960: Franz \& Ferdinand Bauer, masters of botanical illustration. - Endeavour 19: 27-35. Thomas, S. (ed.) 2002: The Encounter, 1802: Art of the Flinders and Baudin voyages - Adelaide.

Vallance, T. G., Moore, D. T. \& Groves, E. W. (eds) 2001: Nature's Investigator the diary of Robert Brown in Australia, 1801-1805 - Canberra.

Watt, A. 2004: Notes on the Robert Brown letter to Dawson Turner. - Int. Dendrol. Soc. Austral. Br. Newsl. 2(12): 5-7.

Watts, P., Pomfrett, J. A. \& Mabberley, D. J. 1997: An exquisite eye: the Australian flora and fauna drawings 1801-1820 of Ferdinand Bauer. - Glebe. 
Wheeler, A. \& Moore, D. T. 1994: The animal drawings of Ferdinand Bauer in the Natural History Museum, London. - Arch. Nat. Hist. 21: 309-344.

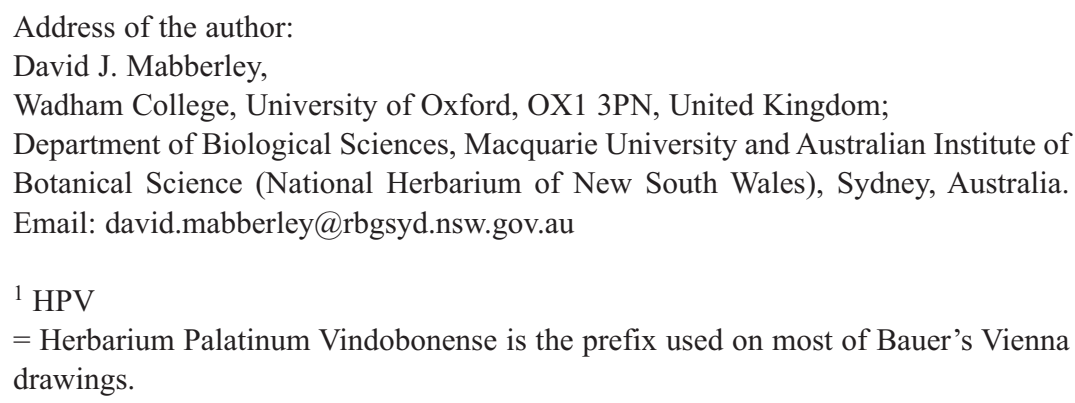

\section{APPENDIX 1}

\section{Robert Brown MS B. 97 (Natural History Museum London) and its ramifications}

This manuscript, entitled "List of sketches of Plants and Animals made during the Voyage of his Majesties [sic] Ship Investigator and subsequently at Port Jackson \& Norfolk Island by Ferdinand Bauer" (Moore 2021) appears at face value to be very straightforward - but it is full of pitfalls.

The contents are a numbered list of animal and plant drawings, the latter arranged according to Linnaeus's Sexual System, but it is not clear when the list was compiled, the title-page being watermarked "SHARP 1804", so it is likely after Investigator reached England in 1805 and was probably an aide-memoire for Brown's work. Importantly, it also includes information about drawings made in South Africa and Timor (Indonesia), as well as at sea (animals). A number of authors have used it to calculate the number of drawings Bauer made during his time on the expedition but, as will be explained below, this is by no means straightforward - and such numbers are likely to be gross underestimates.

For ease of use, the Australian plant drawings were arranged according to the Linnaean system, beginning with Monandria and ending with Polygamia, followed by "Palmae" and then "Cryptogamia" [of which there are merely 10, comprising just two fern entries ("Marsilea", "Ophioglossum", with a later interpolated unnumbered "Azolla") and eight fungal ones, so almost no pteridophytes and no algae, lichens, or bryophytes were drawn. The sequence ends with nos 15301541 "Incert: sed florib: incognit:". There follow the plants from Norfolk Island similarly arranged with palms before cryptogams at the end, the total being 80. Next are Timor plants (60) and those from "Cape of Good Hope" (79).

The animals follow, firstly from Norfolk Island (40 entries) beginning with Birds, then Fish and finally "Insects", which term includes all invertebrates, and then "New Holland" (263 entries beginning with mammals and ending with "Insects"). None of the animal drawings from South Africa or Timor is included.

On the face of it, Bauer would therefore have appeared to have made 2163 drawings (as well as the unlisted Indonesian and African animals). However, examination of the holdings in the Archiv of the Naturhistorisches Museum, Vienna shows that very often there are separate drawings of different 
plants but of the same species being given the same number. i.e., as far as Brown was concerned, this list represents a species not drawing list.

Moreover, very many of the surviving field drawings do not bear "Brown" numbers, which were added to his drawings by Bauer himself, suggesting that he may have overlooked or withheld certain drawings, but see below, where species in certain families of plants were given numbers but these are not found on the drawings. When analysis of the Vienna findings is complete it may be possible to estimate the overall numbers of drawings Bauer made. However, it is not a simple matter of adding up the numbers of pieces of paper (and extrapolating - see below), because Bauer often sketched more than one plant on a single folio. This was particularly true in southern Australia, less so in the north where single subjects indeed often cover very large sheets.

As the entries in B. 97 bear tentative identifications by Brown (a few of which Bauer added to drawings) and later pencil amendments and additions, such that those near the beginning for example often have species-level names, Brown must have examined the drawings as the list was made and later updated it as he worked through his Investigator material and compared it with the drawings that were always in Bauer's possession. And it is important to emphasize "his" herbarium material, because only rarely does he seem to have had access to Bauer's own substantial herbarium, though there are several entries in his Prodromus (1810) where he cites "D[ominus] Bauer". Sometimes such material is in his own herbarium, though Bauer's "top set" is in W, with duplicates of Norfolk Island materials now at K (Brown bought them at the sale of Franz Bauer's effects in the 1840s and, in turn, but still unmounted, were sold on Brown's death (1858). There are also Bauer specimens (e.g. Norfolk Island Meliaceae) in Budapest and likely elsewhere. Generally, it is his specimens that are associated with the drawings; only very occasionally does Bauer add "Mr Brown" as the source of material for his sketch (see above). In short, the two worked far more independently of one another than has been generally supposed. On top of this, of course, Bauer (with his servant) collected alone in Newcastle, New South Wales, and on Norfolk Island, Brown (with his) alone in Tasmania.

Again, amongst the surviving drawings are many drawn by Bauer after the voyage from material grown at Kew from expedition materials, largely seeds sent back by Peter Good, the horticulturist on the voyage (see above). Bauer's sketches of these date from 1806 to 1811, at the end of which year he ceased being employed by the Admiralty (Brown ceasing at the end of 1810).

\section{APPENDIX 2}

\section{Botanical drawings}

This must be read in conjunction with Mabberley \& Moore (1999), which numbering is followed here, with correct(ed) identification or nomenclature (if any) in bold and original attribution with the new information after "W:". N.B. The non-HPV numbers cited on the W drawings refer to B.97 numbers - see Appendix 1.

\section{Hibbertia dealbata}

W: (HPV 1255) pencil drawing with numbers "A" "N 78" "Gulf of Carpentar I p I y S Arnhem Bay \& N Arnhem Bay [sign] Feb 161803 [Bauer and Brown were on Strath Is., Melville Bay, Northern Territory, that day (Vallance \& al. 2001: 367-368)]"; (HPV 1255-a) inked tracing with numbers. 
2 Pachynema complanatum $=$ Hibbertia persquamata Toelken

W: (HPV 1254) pencil drawing with numbers "Gulf of Carpentaria [sign] Jan 261803 [Bauer and Brown were at Cape Shield north of Blue Mud Bay, Northern Territory, that day]" "A 19" "No 675" "Brachystema" - (HPV 1244. [sic]) inked tracing with numbers.

\section{Cochlospermum gillivraei}

W: (HPV 1370-a) pencil drawing (quarto) without numbers "Gulf of Carpentaria" Prince of Wales Island [= Goods Is. (Pallilag), Torres Strait, Queensland] No 20 A No 890 (460).

5 Citriobatus pauciflorus $=$ Pittosporum multiflorum (Benth.) Cayzer \& al.

W: no drawing recognized.

6 Pronaya fraseri $=$ Billardiera fraseri (Hook.) Cayzer \& al.

W: no drawing recognised.

\section{Tremandra stelligera}

W: (HPV 1854/55) pencil drawings [also of a legume] with numbers "Kig [sic] Georg S [King George Sound, Western Australia]" "No 734"; "No 627”.

\section{3, 14 Brachychiton paradoxus}

W: (HPV 1364-a) partly inked pencil tracing "453" "Carpentaria" - associated with original for London watercolour, but re-arranged.

15 Rulingia hermanniifolia = Commersonia hermanniifolia J. Gay ex Kunth

W: (HPV 1374) pencil drawing with numbers "South Head [Sydney Harbour] Aug 271803 \& Farm Coav [Cove, Sydney]" "A" "No 447", but with branches added, likely from a herbarium specimen; (HPV 1373a) inked tracing with numbers.

16 Keraudrenia hookeriana $=$ Seringia hookeriana $($ Walp.) F. Muell.

W: no drawing recognised.

17 Tribulus brownii $=$ Tribulopis pentandra $\mathrm{R} . \mathrm{Br}$.

W: no drawing recognised.

\section{Turraea pubescens}

W: (HPV 1943-a) partly inked tracing “Kappel [Keppel] Bay [Queensland] East coast”.

\section{Toona ciliata}

W: (HPV 1394) pencil drawing with numbers "No 445" "A" "Paterson [i.e. Hunter] River April 11 1804" (Fig. 5). 


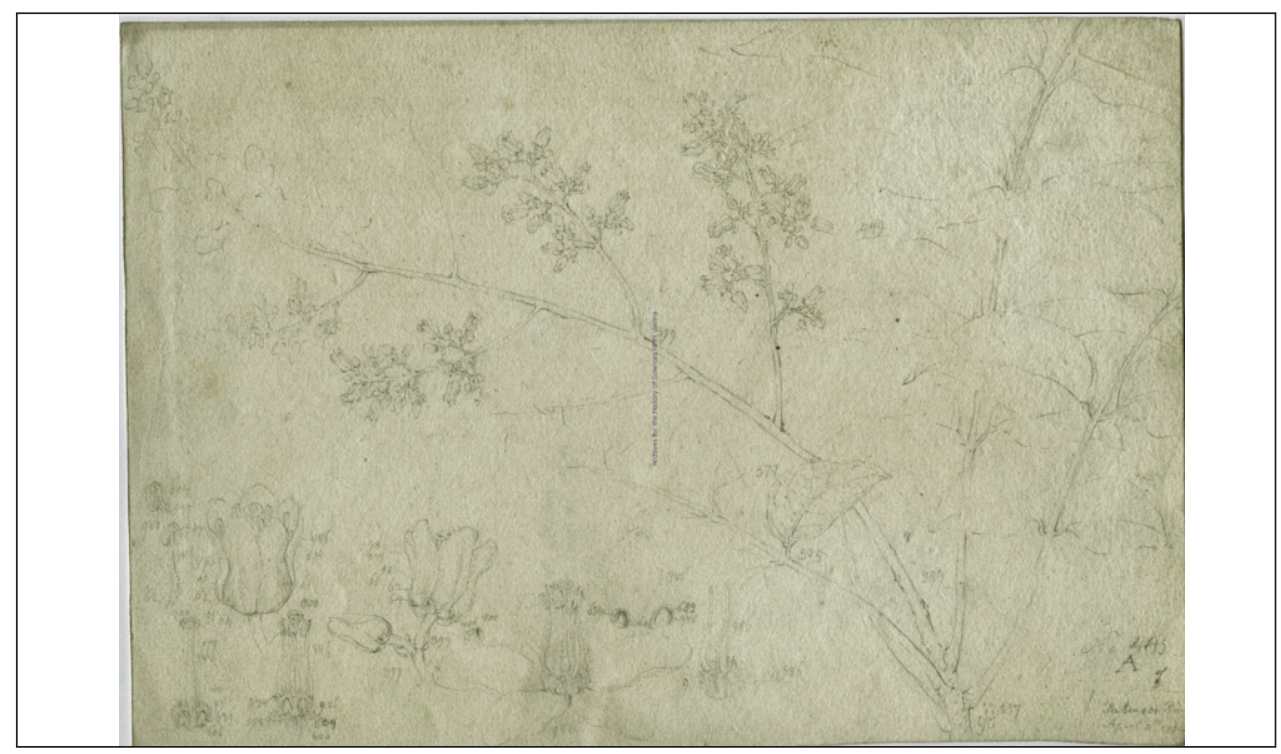

Fig. 5. Toona ciliata M. Roem. (red cedar, Meliaceae). (Archiv, Naturhistorisches Museum Wien). Previously unpublished.

\section{Stackhousia nuda}

W: (HPV 1452) pencil drawing with numbers "No 520" "Sydney Jan 9 1804"; "[verso] "A" "No 520" "No 66"; (HPV 1452-a) proof plate (imprint 22.5 x $17.5 \mathrm{~cm}$ ); (HPV 1453) pencil drawing with numbers "[verso]”No 73" “A” "North shor[e] Port Jackson Jun 1803" “common at Sydney Jan 7 1804”; (HPV 1453a) inked tracing with numbers; (HPV 1453 -b) partly inked pencil tracing without numbers.

\section{Tripterococcus brunonis}

W: (HPV 1456) “K Georg[e] III Sound [Western Australia]" “A” N 67” "No 524”.

\section{Distichostemon hispidulus = Dodonaea hispidula Endl.}

W: no drawing recognised.

\section{Templetonia hookeri}

W: (HPV 1746), pencil drawing with numbers "Gulf of Carpentaria Isl h [North Is., Edward Pellow Group, Northern Territory]" "A" "N 41" "No 1039".

\section{Hovea longifolia}

W: (HPV 1802), pencil drawing with numbers "Bay II East Coast [Port Clinton, Queensland]" "A N. 0 [dot]" "No 1045". First published, with finished watercolour in Mabberley (2017: 116-17). 


\section{Crotalaria medicaginea}

W: (HPV 1803) pencil drawing with numbers "Facing I[sland; 07-08 August 1802] Bay I Kappel [Keppel] Bay [Queensland] East Coast" "A" "N. 37") "No 1048".

\section{Aeschynomene falcata}

W: (HPV 1801) pencil drawing with numbers "Broad Sound \& Northumberland Isl [Queensland]" "A" "N 1106" "N 72" - at least part of watercolour image likely augmented with details from herbarium material.

\section{Senna artemisioides}

W: (HPV 1881), pencil drawing with numbers "No XII South coast [Spencer Gulf, South Australia] 1802" "N 64" "A" No 749".

45 Drosera binata $=$ Drosera pedata Pers.

W: no drawing recognised. See Mabberley (2018) for nomenclature.

52 Agonis marginata $=$ Taxandria marginata (Labill.) J. Wheeler \& N. Marchant

W: no drawing recognised.

54 Calothamnus gracilis = Melaleuca gracilis $(\mathrm{R}$. Br.) Craven \& R.D. Edwards

$\mathbf{W}$ : no drawing recognised.

55 Eucalyptus conferruminata D.J. Carr \& S.G.M. Carr ("E. lehmannii”)

W: no drawing recognised.

59 Myrtella obtusa $=$ ? Lithomyrtus obtusa (Endl.) N. Snow \& Guymer

W: (HPV 1650) pencil drawing with numbers " $\mathrm{N} \mathrm{Co[a]st} \mathrm{Isl} \mathrm{y} 2$ [Pobassoo Is., English Company Is., Northern Territory] Feb 22 1803" "No 823" - basis of Endl., Atakta: t. 18 (1834), but this is $L$. retusa (Endl.) N. Snow \& Guymer; pencil tracing (1650a).

\section{Adenia heterophylla}

W: (flowers; HPV 1318) pencil sketch with numbers "Gulf of Carpentaria Jan 161803 [Bauer was on Winchelsea Is., Northern Territory that day (Vallance \& al. 2001: 342)]"- (fruits on verso; HPV 1319) pencil sketch with numbers "Gulf of Carpentaria “- also bases for Endl., Ic. Gen. Plant.: tt. 114, 115 (1841); (HPV 1319-a) - proof plate.

\section{Mackinlaya macrosciadea}

Likely Mount Westall Passage, Queensland, 26 August 1802 (Mabberley 2017: 122-123 - field drawing at $\mathrm{W})$.

\section{Sambucus gaudichaudiana}

W: field drawing seen 2014. 


\section{Gardenia megasperma}

W: (HPV 843) pencil drawing (fruit) with numbers; verso (flowers) "No 461" "Gulf of Carpentaria Island H [North Is., Edward Pellew Group, Northern Territory]”.

\section{Scyphiphora hydrophylacea}

W: (HPV 863, fruit [\& attached seed drawing] on verso) pencil drawing with numbers "No 183" "Gulf of Carpent N Arnhem Bay [female sign] Feb 161803 [Bauer was on Strath Is., Melville Bay, Northern Territory that day]"; HPV 863a) - inked pencil tracing with numbers.

72 Canthium attenuatum $=$ Psydrax attenuatus $($ Benth.) S. Reynolds \& R. Henderson W: no drawing recognised.

\section{Calotis dentex}

W: (HPV 725) pencil drawing with numbers "Poart [Port] Jackson Parramatta [New South Wales] 1802"; (HPV 725/a) inked tracing with numbers.

\section{Pterocaulon serrulatum}

W: (HPV 727) pencil drawing with numbers "Facing Isl [Queensland] East Coast" "No 46" "A Q No 5" though watercolour has added branches from Bauer's herbarium material; (HPV 727/a) inked tracing with numbers. First published in Mabberley (2017: 108-111).

\section{Ammobium alatum}

W: (HPV 652) "No 63" "New Castle [Newcastle, New South Wales] March 30 1804".

80 Helichrysum scorpioides $=$ Coronidium scorpioides $($ Labill.) Paul G. Wilson

W: no drawing recognised.

\section{Stylidium nymphaeum Wege ("S. scandens")}

Bald Head, King George Sound, Western Australia (see Mabberley 2017: 86-89).

\section{Stylidium fasciculatum}

W: (HPV 836) pencil drawing with numbers "No 8" "P [Bald] Head K G III Sound [King George Sound, Western Australia]".

\section{Scaevola spinescens}

W: (HPV 762-764) - pencil drawings "Bay No III [Fowlers Bay] South coast "No 264" "A"; "No III" "No 255"; "[verso] No 254" "No V [Spencer Gulf] South coast". See Vallance \& al. (2001: 159).

89 Diaspasis filifolia $=$ Scaevola filifolia $(\mathrm{R}$. Br.) K. Sheph.

W: no drawing recognised. 


\section{Brunonia australis}

W: "Shoal Bay Island A [Port Clinton, Queensland]". Bauer reworked his field drawing for his Illustrationes: t. 10 (1813-14). See Mabberley \& Moore (1999: 132, 207); Mabberley (2017: 118-19).

\section{Lysinema ciliatum}

W: (HPV 1170/71) pencil drawings with numbers "Bay I [Lucky Bay, Western Australia] South coast" "No 378" "a" (but watercolour elaborated, likely from herbarium material); "No 407" "b".

\section{Cosmelia rubra}

W: (HPV 1173) pencil drawing (very small) with numbers "K G S [King George Sound, Western Australia] No 409" "b". See Mabberley 2017: 90-91).

\section{Andersonia sprengelioides}

W: (HPV 1132) pencil drawing with numbers "K.G.III Sound Kew May $31^{\text {t }} 1806$ " "A No I". Drawn from material grown at Kew Gardens from seeds collected at King George Sound, Western Australia (Mabberley 2017: 176-177).

\section{Andersonia caerulea}

W: (HPV 1154-a) inked tracing with numbers "K G III Sond [King George Sound, Western Australia] No 408. (1496.) "b"; (HPV 1145/1146) pencil drawings with numbers "K George III Sond" "B" "No 408" "a"; "b" "No 401"; (HPV 1145-a) inked tracing with numbers of "a".

\section{Dracophyllum secundum}

W: (HPV 1174) pencil drawing with numbers "Port J [...] Paramata [Parramatta, New South Wales] 1802" "No 423".

\section{Parsonsia straminea}

W: (HPV 889) pencil drawing with numbers "Paterson river [Hunter River] April 11" "1804" "No 479 " "A".

\section{Wrightia pubescens}

W: (HPV 890) pencil sketch with numbers "in the Gulf of Carpentaria" "No 465" + fr on verso.

\section{Gymnanthera oblonga}

W: (HPV 882): pencil sketch with numbers "No 467" "Gulf of Carpentaria Isl IIII [? one of the South Wellesley Islands, Queensland]...”

104 Sarcostemma viminale $=$ Cynanchum viminale $(\mathrm{L}$.$) Bassi subsp. australe (R. Br.) Meve \&$ Liede

W: no drawing recognised. 
105 Brachystelma glabriflorum $=$ Ceropegia glabriflora (F. Muell.) Bruyns

W: no drawing recognised.

106 Logania pusilla $=$ Orianthera pusilla (R. Br.) C.S.P. Foster \& Conn

W: no drawing recognised.

\section{7 ? Solanum hystrix}

W: (HPV 1047) pencil drawing with numbers "No 344" "A" "No V [Spencer Gulf, South Australia] South coast"; "Facing Isl Keppel Bay Shoal Bay [Queensland]".

(HPV 1047-a) inked tracing with numbers; (HPV no no.) partly inked pencil tracing without numbers “.. 344... 1656". These localities do not match the distribution of S. hystrix.

\section{Anthocercis viscosa}

W: [Anthocercis viscosa/Eremophila glabra] (HPV 973/974) pencil drawings with numbers "K G" "K George III sound [King George Sound, Western Australia]" "No 21" "a" "No 947"; "No III" "No III South coast [Fowlers Bay, South Australia]" "942” No 22" “A” "b” (see Lack 1998: 257-261)

\section{Eremophila glabra}

W: [Anthocercis viscosa/Eremophila glabra] (HPV 973/974) pencil drawings with numbers "K G" "K George III sound [King George Sound, Western Australia]" "No 21" "a" "No 947"; "No III" "No III South coast [Fowlers Bay, South Australia]" "942" No 22" "A" "b"; [Eremophila glabra] (HPV 973-a) inked tracing for Endl., Ic. Gen. Pl. t. 92 (1839).

\section{Pityrodia salviifolia}

W: (HPV no no.) inked tracing with numbers "Bay East Coast [Queensland]No 25 (1589)"

117 Hemigenia purpurea $=$ Westringia sp.

W: no drawing recognised.

121 Enchylaena tomentosa $[?=$ Maireana sp.)

BM: According to Brown's descriptive slip B. 65. 50/71 "Ic Bauer Enchylaena \{ab Inlet XII [Spencer Gulf, South Australia]\}". N.B. Chenopodiacea/Amaranthaceae, a "destroyed family" (Riedl 1981).

123 Gyrostemon sheathii Fitzg. ("G. ramulosus”)

See Mabberley \& Moore (1999: 84).

146 Decaisnina brittenii (Blakely) Barlow ("Amyema pendulum”)

Likely Point Blane, Blue Mud Bay, Northern Territory, 28 January 1803. See Thomas (2002: 9495), Clarkson \& Mabberley (2005: 130). N.B. Loranthaceae, a "destroyed family" (Riedl 1981). 


\section{Allocasuarina torulosa}

W: (HPV 455) "Sydney to Parramatta July 20 1804". See Mabberley (2017: 134-135). N.B. Casuarinaceae, a "destroyed family" (Riedl 1981).

\section{Ottelia ovalifolia}

W: (HPV 333) - pencil drawing with numbers [enlargements of seq.]" No 900"; (HPV 334) - pencil drawing with numbers "A" "No 898" "(760)" "from Tungaby [Toongabbie] to Hawkesbury [River, New South Wales] Nov 21" "1803", [verso] "No VIII [?Spencer Gulf, South Australia]". See Mabberley (2017: 143). N.B. Hydrocharitaceae, a "destroyed family" (Riedl 1981).

162 Dendrobium discolor $=$ D. brownii F. Dietr.

W: (HPV 367) - pencil drawing with numbers but without locality (Mabberley 2017: 114-115; 2019: 192-93). See Mabberley \& Moore (2021) for nomenclature.

165 Spiranthes sinensis subsp. australis

W: (HPV 424) pencil sketch with numbers "1273" “(813)" "Farm Cove Sydney Feb 21 1804".

\section{Thelymitra ixioides}

W: (HPV 411) pencil sketch (incl. verso) with numbers, "Sydney Aug 11 1803" "No 1296" “(800)”; pencil tracings with numbers, re-arranged (HPV 411.a, 411.c)

\section{Thelymitra canaliculata}

W: (HPV 433) pencil sketch with numbers "No 1300 King G III Sound [King George Sound, Western Australia]” "(1441)".

\section{Thelymitra tigrina}

W: (HPV 434) pencil sketch with numbers “(1442)" "No 1301" "K George III Sound [King George Sound, Western Australia]".

\section{Thelymitra carnosa}

W: (HPV 428) pencil sketch with numbers "Sydney Farm Cove" "No 1299" "(817)" "Georges River Sep 29 1803"; (HPV 428a) inked tracing with numbers "Sydney Fawn Count N 1299 (817)".

\section{Thelymitra fuscolutea}

W: (HPV 435) pencil drawing with numbers "K G III Sound [King George Sound, Western Australia]" "No 1302" (1443)".

\section{2: Thelymitra venosa}

W: (HPV 412) pencil sketch with numbers "No 1298" (801)" "Sydney Nov 12 1803". 


\section{Epiblema grandiflorum}

W: (HPV 437) pencil sketch with numbers "K G III Sound [King George Sound, Western Australia]" "(1445)" "No 1303”.

\section{6: Diuris aurea}

W: (HPV 413) pencil sketch with numbers”No X” "Sydney Sep 25 1803” “(802)”.

\section{7: Diuris maculata}

W: (HPV 371 - folded sheet) pencil drawing with numbers "Port Jackson Sydney 1802" (a second, epiphytic, species on verso)

\section{8: Diuris pedunculata}

W: (HPV 419) pencil sketch with numbers "No IX" "Sep $8^{\text {th }} 1803$ from Paramata [Paramatta] to Hawksb [Hawkesbury River, New South Wales]” “(803)” plus image on verso.

\section{Diuris emarginata var. pauciflora}

W: (HPV 436) pencil drawing with numbers "No VI." "K. G III Soud [sic; King George Sound, Western Australia]".

\section{2: Cryptostylis ovata}

W: (HPV 380) pencil sketch with numbers "No X[?] K G III S [King George Sound, Western Australia]" "(758.b.)".

\section{Cryptostylis erecta}

W: (HPV 416) pencil sketch with numbers "No 1330" "Sydney April 30 1805".

\section{Prasophyllum striatum}

W: (HPV 417) pencil sketch with numbers "No 1275" "Sydney Molamola [?Woolloomooloo] May 21 1804 ".

\section{Pterostylis nutans}

W: (HPV 394) pencil sketch with numbers "No 1313" "Sydney White Farm [White's farm, Petersham, Sydney - see Vallance \& al. 2001: 520] July 6th 1804" [great detail on verso].

\section{Pterostylis gibbosa}

W: (HPV 390) pencil sketch with numbers "No 1320" "Cow Pastras [Cowpastures, southwest Sydney] Oct 9th 1803" [verso] "No 1321" Prospect [Hill] Oct 8 1803".

\section{Caleana major}

W: (HPV 386) pencil sketch with numbers "No 329" "Caleana major" "Sydney Sept 22[?]" "Sydney Oct 17 " "1802". 


\section{Acianthus fornicatus}

W: (HPV 440) pencil sketch with numbers "Port Jackson Sydney 1802" "No 1327” "(1448)".

\section{Acianthus exsertus}

W: (HPV 409) pencil drawing with numbers "N 1324" "(798)" "North Rock[s] Paramatta [New South Wales] May 12 1804".

\section{Cyrtostylis reniformis}

W: (HPV 439) pencil sketch with numbers “(1447)" "No 1328" "Port Jackson 1802".

\section{Lyperanthus suaveolens}

W: (HPV 369) pencil drawing with numbers “Sydney Aug 27 1803”, image verso "No XI [sic]”; inked tracings with numbers (HPV 369a, 369b)

\section{Caladenia testacea}

W: (HPV 403) pencil sketch with numbers "Sydney Sep 2 1803", "No 1289A” “(792)”.

\section{Chiloglottis reflexa sensu lato}

W: (HPV 388) pencil sketch with numbers including magnified seed "Duk Bruge [Duck Bridge] R. Parramatta [New South Wales] July 20 1804" [orig. for 202A and therefore part of 202B (middle plant new)]

\section{Calochilus campestris}

W: (HPV 441 mounted on herbarium sheet, pencil sketch with numbers "Shaol Water Bay [male sign; Shoalwater Bay, Queensland]" "(1449)" "No 1285".

\section{Habenaria ochroleuca}

W: (HPV 427) pencil sketch with numbers "No 1271" "North Cost [sic] I y2 [female sign; Pobassoo Is., English Company Is., Northern Territory] Feb 18 1803”.

\section{Calectasia cyanea}

W: (HPV 279) pencil drawing with numbers "King Georg III Sound [King George Sound, western Australia]" "A" "No 589"; also the basis for engraving in M. Flinders Voyage Terra Australia, atlas t. 10 (1814). N.B. Dasypogonaceae, a "destroyed family” (cf. Riedl 1981).

\section{Azolla pinnata}

W: (HPV 231) pencil drawing with numbers, also the basis for Sansom's engraving in Flinders, Voy. Terra Australis Atlas t. 10 (upper) (See Mabberley 2017: 140-141).

\section{Aseroe rubra}

W: (HPV 225) pencil drawing with numbers "Parramatta [New South Wales]" "May $12^{\text {th }} 1804$ ". 
233 Comarophyllus lilacinus $=$ Cantharellus lilacinus Cleland \& Cheel

W: Field drawing seen 2014.

234 (upper) ? Entoloma sp.

W: (HPV 224a) - watercolour (?by Zehner brothers) arranged differently from the London watercolour but based on same Bauer field drawing.

\section{4 (lower) ? Entoloma sp.}

W: (HPV 222a) - watercolour (?by Zehner brothers) arranged differently from the London watercolour but based on same Bauer field drawing.

\section{5 (upper) ? Hygrocybe sp.}

W: (HPV 223a) - watercolour (?by Zehner brothers) arranged differently from the London watercolour but based on same Bauer field drawing.

\section{Clavulinopsis miniata = Clavaria miniata Berk.; Geoglossum sp.}

W: field drawing seen 2014; (HPV 223a) - watercolour (?by Zehner brothers) arranged differently from the London watercolour but based on same Bauer field drawing.

\section{APPENDIX 3}

\section{Zoological drawings}

This must be read in conjunction with Wheeler \& Moore (1994), which numbering and nomenclature are followed here, with corrected identification (if any) in bold and original attribution with the new information after "W:". N.B. The numbers cited on the W drawings refer to B.97 numbers - see Appendix 1.

1(1), 2(1A) Hydromys chrysogaster

W: "Port Jackson 1802”. See Mabberley (2017: 105).

3(2), 4(2A) Perameles bougainville

W: "South coast 1802" "no III [Fowlers Bay, South Australia]". See Thomas (2002: 72-73); Mabberley (2017: 94-95).

5(3), 6(4), 7(5), 8(6), 9(7) Phascolarctos cinereus

W: "from the south of Port Jackson Aug 15 1803". See Mabberley (2017: 138-139).

10(8), 11(9) Vombatus ursinus

W: "Kings Island [King Island, Tasmania] 1802". 
16(14) Psephotus dissimilis

W: "No 46" "Gulf of Carpent [Caledon Bay, Mount Caledon].... Feb. 6 1803".

\section{1(19) Platycercus venustus venustus}

Northern Territory, 6 Feb. 1803 (Mabberley \& Moore 2021). Robert Brown MS descriptive slip (BM) Z1 f. 323 has "Psittacus venustus Brownii Temminck in Linn. Soc. Trans. ... Arnheim [sic] Bay Feb $6^{\text {th }} 1803$ [likely Mount Caledon, Caledon Bay, Arnhem Land, Northern Territory] desc d ${ }^{\circ}$ do", "Fig. Pict. Ferd. Bauer. No 19". This is likely also the "Psittacus splendidus" of Robert Brown's diary (Vallance \& al. 2001: 366).

22(20), 23(21) P. zonarius zonarius = Barnardius zonarius zonarius $($ Shaw)

W: "No 39" "N IX South coast [Memory Cove, South Australia]". See Mabberley 2017: 100101).

26(24) Trichoglossus haematodus moluccanus $=$ T. moluccanus moluccanus (Gmelin)

W: "No 44" "I Broad Sound [Queensland] 1802".

\section{7(25) Philemon corniculatus}

W: "No 68" "Shoal Water Bay [Queensland] 18[02]".

28(26) Litoria raniformis (Keferstein) ("L. aurea")

King Island, Tasmania. See Thomas (2002: 74).

\section{9(27) Egernia cunninghami}

W: "Egernia kingii" - pencil sketch with numbers + "C", "D", "E", "G"; Bauer MS: "No 187" "South Coast".

30(28), 31 (28A) Brachaluteres baueri = B. jacksonianus (Quoy \& Gaimard)

W: "South Coast [perhaps Petrel Bay, St Francis Is., Nuyts Archipelago, South Australia]" (Mabberley 2017: 92-93).

\section{2(29), 33(29A) Anoplocapros inermis}

W: "No 235" "South coast".

34(30), 35(30A) Bigener brownii = Acanthaluteres brownii (Richardson)

W: mounted pencil drawing numbers incl. Roman numbers + X, "with gold", "No 226", "South Coast"; the finished watercolour the sole basis (and therefore holotype) for Richardson's description.

36(31), 37 (31A) Periophthalmus sp.

W: "No 239", "Gulf of Carpentaria". 


\section{8(32), 39(32A) Favonigobius? sp.}

W: "No 240" "Gulf of Carpentaria Isl I [Maria Is., Sir Edward Pellew Group, Northern Territory; see Vallance \& al. (2001: 335)]”.

\section{0(33) Pterois sp.}

W: "Shall W [= Shoalwater] Bay [Queensland]" "No 224". See Mabberley (2017: 120-121).

\section{1(34), 42(34A) Enoplosus armatus}

W: "No IIII [= Petrel Bay, St Francis Is., Nuyts Archipelago, South Australia] South coast" "No 243".

43(35), 44(35A) Odax acroptilus = Heteroscarus acroptilus (Richardson)

W: "No 230; "South coast". The watercolour was the sole basis (and therefore holotype) for Richardson's description.

\section{5(36) Siphonognathus radiatus}

W: "No IIII South Coast" "N IIII [= Petrel Bay, St Francis Is., Nuyts Archipelago, South Australia]" "No 244".

46(37), 47(37A) Exocoetus sp.

W: “[female (Venus) sign] May 61803 Lat $20^{\circ}$ [?30 ; at sea off Western Australia] No 234”.

\section{8(38) Phyllopteryx taeniolatus}

W: "South coast" "N 215"; fins re-arranged for finished watercolour. See Mabberley (2017: 92-93).

49(39), 50(40), 51(40A) Portunus pelagicus = P. armatus (L.)

W: field drawing with numbers "[anchorage] XIII [Kangaroo Is., South Australia]" (see Lack 1998: 268; Thomas 2002: 22-23).

52(41) Gasteracantha minax = Austracantha minax (Thorell)

W: “No 259” \& "No 260" -’Norfolk Island Jan 10 1805”; "Norfolk Isl Jan 14 1805”. See Mabberley (2017: 162-163).

\section{APPENDIX 4}

Watercolours of Australian plants and animals attributed to Ferdinand Bauer and held in the Linnean Society of London

Also in London are other drawing attributed to Bauer. The Linnean Society of London has a handful of other Australian plant watercolours (and also one of arthropods) attributed to him. How they came to the Society is unclear, but it is conceivable they ultimately originate from the sale of Aylmer Bourke 
Lambert's library in 1842 or possibly from Bauer's early, and somewhat eccentric, biographer, Jan Lhotzky. One, likely coloured by Bauer himself, is of Lambertia formosa Sm. (Proteaceae), the mountain devil of eastern Australia, named after Lambert by J. E. Smith; Bauer's drawing was redrawn from a sketch made in New South Wales, "corrected from wild Specimens" in Smith's herbarium (LINN-SM), both likely sent from Sydney by Surgeon John White in the late 1780s (Mabberley 2017: 62, 2019: 238). Based on this, an engraving by Joseph Banks's engraver, Daniel Mackenzie, was published in the Transactions of the Linnean Society in 1798. Part of the original illustration was later engraved by J. Watts and published in the Botanical Register in 1821, when the watercolour was still in Lambert's hands.

\section{Enigmatic drawings attributed to Bauer}

Much less known is a smaller watercolour (MS 622 f. 5, $332 \times 236$ mm; no watermark; Fig. 6) of an emu-bush from Australia, Eremophila longifolia (R. Br.) F. Muell. (Scrophulariaceae). Marked by the late Gavin Bridson as the work of "F Bauer" and catalogued as the work of Ferdinand Bauer, the subject of this unpublished drawing was identified by Bob Chinnock of Adelaide Botanic Garden only in 2017.

Bauer made a colour-coded, pencil field sketch of this species whilst working with Robert Brown on what is now Mount Brown in the Flinders Ranges, South Australia, in March 1802. If that was the basis for the watercolour, its small size, perhaps reflecting the dearth of paper during his time in Australia, suggests that Bauer would have completed the watercolour there before returning to Britain with Brown in 1805 (Mabberley 2017: 152-53). If this were to be so, he would likely have made the watercolour, then therefore the first made of any South Australian plant by a European, in a rented house on the site of today's Royal Botanic Garden Sydney, using a locally made travelling desk (now preserved in the Economic Botany Collection at the Royal Botanic Gardens, Kew), one of the oldest surviving pieces of Australian colonial furniture (Mabberley 2017: 152).

However, the drawing is "No. 5", one of a series (MS 622) of plants, 1-2, 4-5 with the sixth being the arthropods, all of the same size. Some of these are less accomplished and some are notable for shadows (unusual in Bauer's work, though found in his Dali-esque fungal drawings done for the Admiralty - see above) depicted underneath sprigs of leaves, "No 1", of a species of Myoporum (also Scrophulariaceae) bearing in pencil in an unknown early hand "App. F. Bauer del.". The quality of the work suggests that if it was by Bauer, it must have been in his old age. However, any attribution to Bauer at all has now been thrown seriously into doubt through the examination, in another context (Mabberley 2019: 268, 270-73), of the papers of the Australian Surveyor General, Sir Thomas Mitchell (1792-1855), papers preserved in the State Library of New South Wales in Sydney.

Among the drawings filed there as PXD $627 \mathrm{f} .12$ (Fig. 7) is the same image of a "cucumber" (an undescribed species) as "No. 4" in the "Bauer" series (both with shadows drawn) in London (Fig. 8). One is a copy of the other, but which is the original, who made the copy and, more importantly, who was the original artist? The image is of a species of "Cucumis" (Cucurbitaceae) and the Sydney drawing has an inscription, "Cucumber - banks of the Gwydir \& flat rich ground S of it bet" it \& the first chain of Ponds. (There is a variety with a yellow flower and dark green streaks on the cucumber like a melon -)". Mitchell was on the Gwydir River (New South Wales) early in 1832 (after Bauer's death), when he wrote in his Three expeditions into the interior of Australia, vol. 1: 88 (1838), "We found a new species of cucumber in the rich soil near the water, of about the size of a plum, the flower being of a purple colour.....the latitude of this camp was $29^{\circ} 28^{\prime \prime} 34^{\prime \prime}$ S". Moreover, he here discussed spiders which match those in the arthropod drawing in London. 


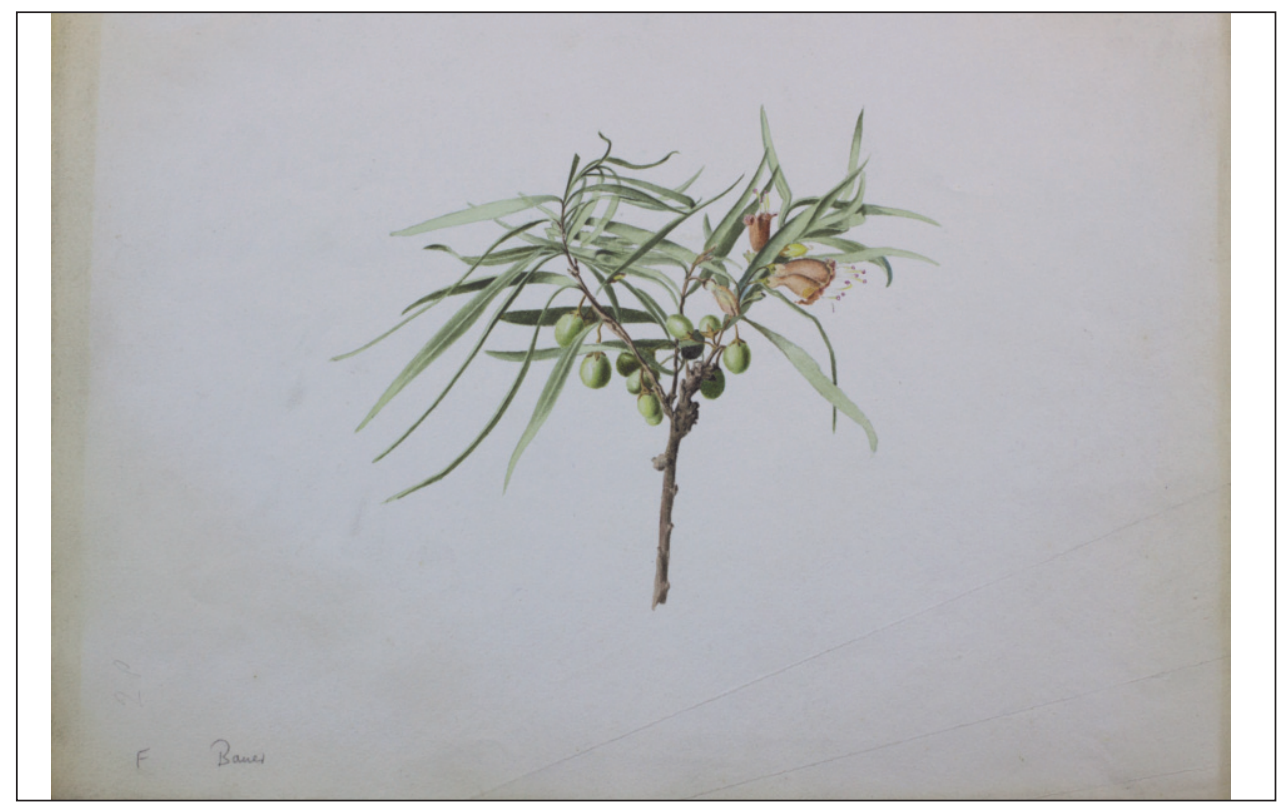

Fig. 6. Eremophila longifolia (R. Br.) F. Muell. (Scrophulariaceae). Watercolour by unknown artist. Linnean Society of London MS 622 f. 5.

In his preface (pp. iii-iv), Mitchell wrote "neither his pencil nor his pen has been allowed to pass the bounds of truth", suggesting the artist was Mitchell himself; indeed, the book is illustrated with plates lithographed from his original drawings. However, Mitchell's original watercolours (see Mabberley 2019: 2723) are nowhere near as accomplished as these, strongly suggesting the Linnean Society drawings are by another hand. John Lindley wrote up the plants for Mitchell's book and, at the same time, was collaborating with Franz Bauer, Ferdinand's brother (Lack 2015: 373-5). Perhaps, then, the "F Bauer" on the drawings is Franz Bauer, the Sydney version of the Cucumis being a copy annotated by Mitchell. This needs further work by one immersed in the oeuvre of Franz Bauer - but, certainly, Ferdinand Bauer seems to have had nothing to do with it.

This is not the first mis-attribution of drawings to Bauer, as a set of 60 watercolours in Naturhistorisches Museum Vienna so attributed since 1832 have recently been convincingly shown to be the work of Joseph Knapp (1810-67) with two possibly by Knapp's father, Johann (1778-1833), court painters to the Archdukes Anton Viktor and Johann (Mabberley 2017: 216-18, 220-21: Riedl-Dorn \& Riedl 2019; cf. Lack 2003). But there is still a niggling problem with two of these "Knapp" drawings in that they are on different paper from that used for the others and were painted in a different way (Mabberley 2017: 216; Riedl-Dorn $\&$ Riedl 2019). Perhaps they were merely the property of Bauer when he died. He seems to have been an intimate of the Knapps, and it was he who proposed that the elder Knapp be commemorated in "Knappia" for what is now Rhynchoglossum Blume (Gesneriaceae), Bauer's Timor drawing of which was incorporated in Knapp's famous monumental painting, Huldingung an Jacquin (Jacquin's Denkmal) now hanging in the Belvedere Palace in Vienna. But Brown plumped for Antonia instead, commemorating one of the archdukes (Mabberley \& Moore 1999: 210; Mabberley 2017: 199-201), though that was a later homonym of Antonia Pohl (Loganiaceae, South America). 


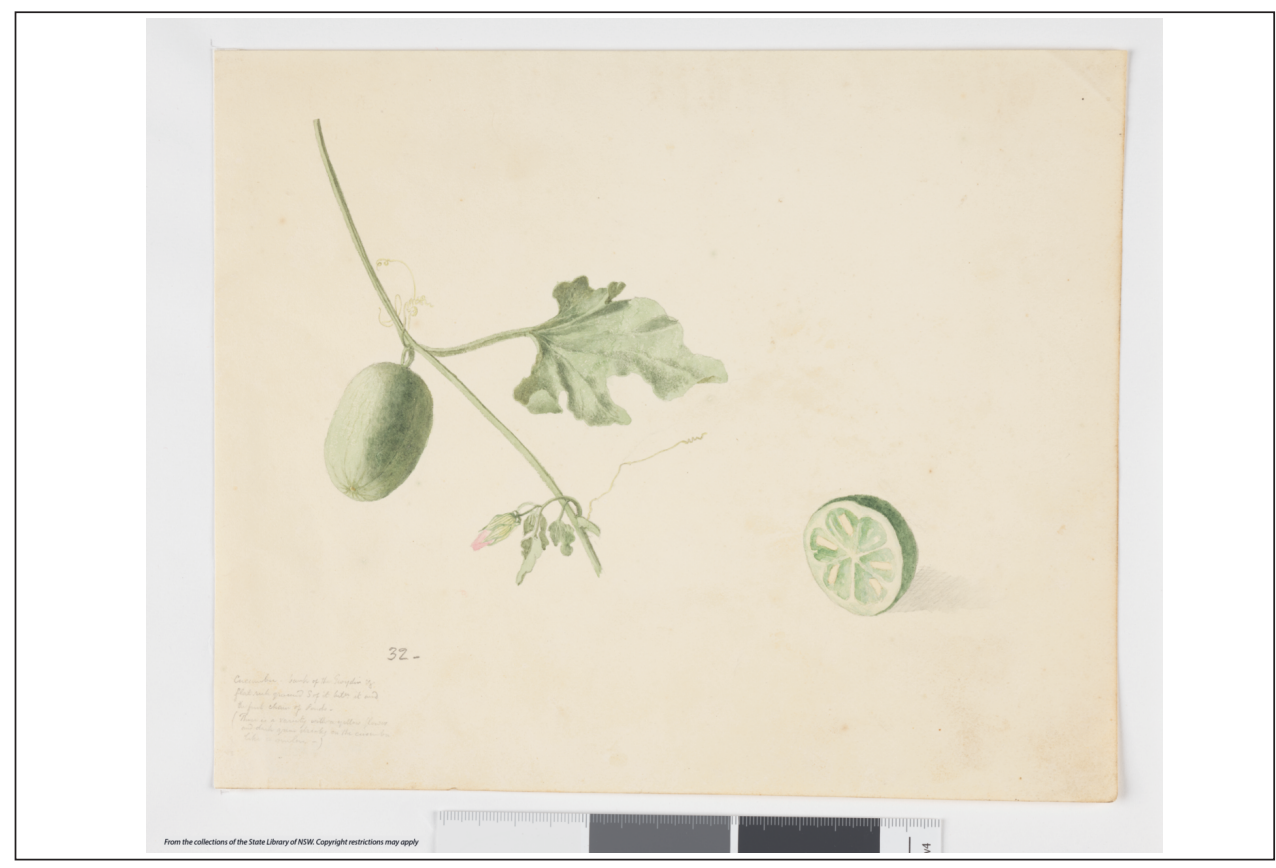

Fig. 7. Cucumis sp. (Cucurbitaceae) by unknown artist (State Library of New South Wales PXD 627 f. 12).

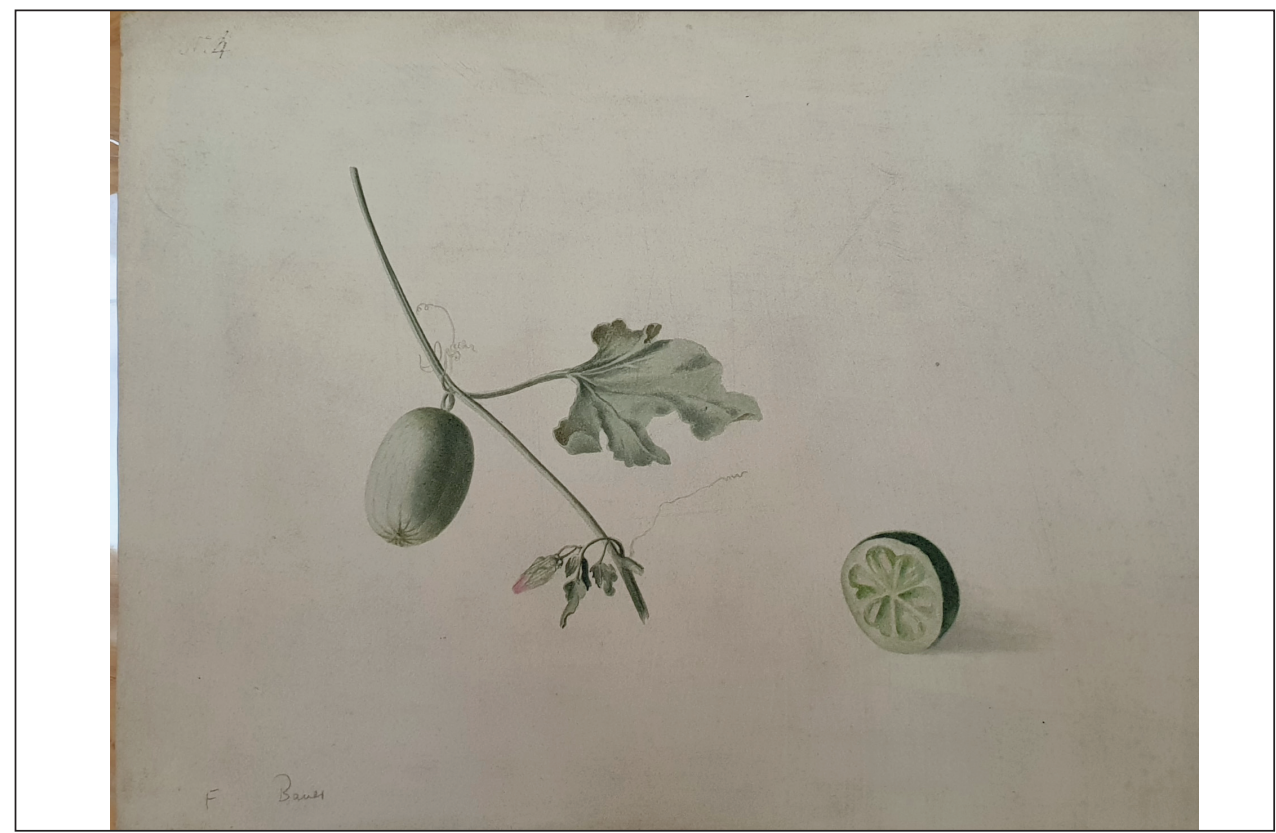

Fig 8. Cucumis sp. (Cucurbitaceae) by unknown artist (Linnean Society of London MS 622 f. 4). 